\title{
BAHASO JAEK DALAM MASYARAKAT SIULAK KERINCI: KAJIAN PRAGMATIK
}

\section{BAHASO JAEK USED BY THE SPEAKERS OF SIULAK LANGUAGE IN KERINCI: PRAGMATIC STUDY}

\author{
Yelnim \\ Sekolah Tinggi Ilmu Ekonomi Sakti Alam Kerinci
}

Naskah diterima: 10 Maret 2018; direvisi: 18 Mei 2019; disetujui: 20 Juni 2019

\begin{abstract}
The research is aimed at analyzing bahaso jaek used by the speakers of Siulak language in Kerinci. The analysis focuses on the function of bahaso jaek. The data are collected by using observational method with interview, record, and note-taking technique. The analysis is conducted by using distributional method with substitution, deletion, and insertion techniques in order to figure out the form of bahaso jaek. The data are also analyzed by using translational , referential, and pragmatic identity method to describe the meaning, and the function of bahaso jaek. The analysis is related to the concept proposed by Chaer (1994); and Wardhaugh (1986); and Searle (1969). The result shows that there are three functions of bahaso Jaek. They are (1) representative, (2) directive, and (3) expressive. Expressive is used as the highest frequency. This implies that through this function, the feeling of the speaker can be expressed profoundly.
\end{abstract}

Keyword: bahaso jae;, taboo language; Siulak Kerinci language;

Abstrak

Penelitian ini bertujuan untuk menganalisis bahaso jaek digunakan oleh penutur bahasa Siulak di Kerinci. Analisis ini berfokus pada fungsi jaek bahaso. Data dikumpulkan dengan menggunakan metode observasional dengan wawancara, catatan, dan mencatat teknik. Analisis dilakukan dengan menggunakan metode distribusional dengan substitusi, penghapusan, dan teknik penyisipan untuk mengetahui bentuk jaek bahaso. Data juga dianalisis dengan menggunakan translasi, referensial, dan metode identitas pragmatis untuk menggambarkan arti, dan fungsi bahaso jaek. Analisis ini berkaitan dengan konsep yang diajukan oleh Chaer (1994); dan Wardhaugh (1986); dan Searle (1969) hasil an menunjukkan bahwa ada tiga fungsi bahaso Jaek. Mereka adalah (1) perwakilan, (2) direktif, dan (3) ekspresif. Ekspresif digunakan sebagai frekuensi tertinggi. Ini berarti bahwa melalui fungsi ini, perasaan pembicara dapat dinyatakan mendalam.

Keyword: bahaso jaek; bahasa tabu; bahasa Siulak Kerinci;

\section{PENDAHULUAN}

Bahaso jaek merupakan salah satu bentuk bahasa lisan di Siulak kabupaten Kerinci yang menjadi warisan budaya leluhur dan masih ada dalam kehidupan masyarakat. Proses pewarisan dilakukan secara lisan dari generasi dulu sampai ke generasi sekarang. Keberadaan bahasojaek di masyarakat Siulak Kerinci menjadi daya untuk melampiaskan ungkapan 
ketidaksenangan, kebencian, pencelaan atau ketidakpuasan terhadap ucapan dan tindakan terhadap situasi yang tengah dihadapinya.

Salah satu unsur yang berpengaruh dalam pembentukan bahasojaek Siulak adalah alam. Alam menjadi sumber pengetahuan yang dapat dipergunakan dalam mengatur kehidupan masyarakat siulak. Orang Siulak berguru dari alam. Mereka mempergunakan alam sebagai kiasan baik yang berupa perintah yang harus ditaati pedoman dalam berinteraksi maupun yang berupa larangan sosial. Larangan sosial dapat berupa kata, benda, tindakan,atau orang yang tidak diinginkan oleh suatu kelompok, budaya atau masyarakat. Bentuk larangan-larangan seperti ini lazim disebut juga dengan bahasa tabu.

Tabu merupakan larangan terhadap sesuatu. Tabu adalah pantang; sesuatu yang terlarang dikerjakan menurut adat, agama, atau kebiasaan setempat (Usman, 2002:434). Bahasa tabu berhubungan sangat erat dengan bermacam aspek kehidupan seperti budaya, keyakinan dan kepercayaan yang bertolak dari tradisi dan kebiasaan yang berlaku dalam kehidupan masyarakat. Masyarakat Siulak menyebut bahasa tabu dengan sebutan bahaso jaek.

Bahasojaek sama dengan bahasa larangan untuk berbicara mengenai apapun yang berhubungan dengan tuturan karena alasan agama, kepantasan, atau kesantunan. Masyarakat Siulak sangat menghindari tindakan dan perkataan yang terlarang merefleksikan adat istiadat dan pandangan masyarakat. Ada beberapa kata yang boleh diucapkan dalam situasi tertentu, tetapi tidak dalam situasi yang lain seperti terdapat larangan mengucapkan kata lauk yang secara umum berarti ikan, daging, atau sejenisnya, kata ini sering diucapkan oleh pedagang ikan ditengah-tengah pasar atau menjajakan ikan mengelilingi desa Siulak dimana pedagang tersebut telah terbiasa dilingkungannya sendiri menyebutkan lauk sebagai ikan. Lauk bagi masyarakat Siulak sangat dilarang diucapkan karena bersinggungan dengan bagian tubuh laki-laki. Maka dari itu masyarakat Siulak tidak akan pernahmengucapkan kata-kata tersebut ditempat tertentu karena tidak pantas dan tidak santun.

Berangkat dari fenomena tersebut, dalam artikel ini dibicarakan tentang bahaso jaek yang digunakan oleh 
masyarakat Siulak Kerinci. Tujuan penulisan artikel ini adalah untuk mengidentifikasi bentuk, makna, dan fungsi bahaso jaek.

Pengumpulan data dilakukan dengan menggunakan metode observasi, teknik wawancara, catat, dan rekam. Data dianalisis menggunakan metode padan translasional, padan referensial, dan padan pragmatik untuk menentukan fungsi bahaso jaek (Sudaryanto, 1983). Analisis dilakukan dengan menghubungkan pada teori Chaer (1994); Wardhaugh(1986); dan Searle (1969).

Penelitian yang serupa
sebelumnya telah dilakukan oleh
Kusmana dan Afria (2018) tentang Analisis Ungkapan Makian dalam Bahasa Kerinci: Studi Sosiolinguistik. Penelitian tersebut Penelitian ini mencoba menjawab bentuk dan karakteristik ungkapan Makian dalam bahasa Kerinci. Penelitian ini bertujuan untuk menjelaskan,, menganalisis dan mendeskripsikan ungkapan makian yang ada di Kabupaten Kerinci.

Temuan data di lapangan referens dan bentuk penggunaan ungkapan makian dapat disimpulkan bahwa penggunaan bahasa makian di kabupaten Kerinci berdasarkan pemerolehan inventarisasi dan analisis data di lapangan didapatkan 7 bentuk makian, yaitu bentuk keadaan, kekerabatan, binatang, mahkluk halus, bagian tubuh, profesi, dan seruan. Jumlah dari semua data yang dihimpun dari 7 bentuk makian tersebut diperoleh 170 data makian. Dari temuan data tersebut didapatkan bahwa bentuk makian keadaan mendominasi data sebanyak 85 data (50\%), hal ini disebabkan di dalam bentuk keadaan ini mempunyai turunan atau referensinya sebanyak 4 turunan, yakni tindakan, sifat, sumpah serapah, dan penyakit. Berikutnya adalah bentuk bagian tubuh sebanyak 21 data (12\%); bentuk seruan sebanyak 18 data (11\%); bentuk profesi sebanyak 13 data (8\%); bentuk etnis 6 data (4\%); dan terakhir bentuk mahkluk halus 4 data (2\%). Dalam pengungkapan bahasa makian tersebut tentu ada beberapa factor penyebab munculnya makian, diantaranya adalah factor social dan situasional. Dengan adanya bahasa makian dan factor penyebabnya terdapat dampak penggunaan bahasa makian itu sendiri menurunnya kualitas bahasa dan rendahnya gejala-gejala social.

\section{TEORI}


Bahaso jaek merupakan bahasa lisan yang masih digunakan dalam kehidupan masyarakat Siulak Kabupaten Kerinci, Propinsi Jambi sebagai ungkapan ekspresi kemarahan, kebencian, dan ketidaksukaan kepada lawan tutur. Bahasojaek tergolong sebagai tuturan agresif (verbal aggretion) yang bertujuan untuk menyakiti atau menyerang lawan tutur.

Penggunaan tuturan agresif menurut Jay (1999:57), secara umum memiliki dua tujuan utama, yaitu untuk bermusuhan (hostile aggresion) dan untuk mendapatkan keuntungan tertentu (instrumental aggresion).

Penggunaan bentuk bahasa agresif atau bahasatabuyang bertujuan untuk menunjukkan permusuhan merupakan bentuk kemarahan, kebencian, atau ketidaksukaan penutur. Hal ini dapat menyebabkan penutur merasa tersakiti oleh perkataan atau perlakuan lawan tutur (Oktavianus dan Revita, 2013).

Sementara itu, penggunaan bentuk bahasa agresif dengan tujuan mendapatkan keuntungan tertentu, seperti untuk mencemooh, menghina, mengancam atau merendahkan lawan tutur untuk tujuan tertentu. Penggunaan tuturan agresif dalam konteks sosial merupakan salah satu bentuk bahaso jaek.

Dalam berbahasa, seorang penutur tidak hanya berfungsi untuk menginformasikan suatu hal, tetapi mengandung fungsi lain. Searle (1969) membagi fungsi tuturan ke dalam lima kategori, yaitu sebagai berikut:

a) Representatif: pada ilokusi ini penutur terikat pada kebenaran proposisi yang diungkapkan. Dalam representatif ini terdapat maksud menyatakan, mengusulkan, membual, mengeluh, mengemukakan pendapat, dan melaporkan. Umumnya representatif cenderung netral dari aspek prinsip sopan santun, kecuali tindak membual biasa dianggap tidak sopan.

b) Direktif: tuturan ini bertujuan menghasilkan suatu efek berupa tindakan yang dilakukan oleh penutur. Contoh tindak tutur direktif di atas misalnya memesan, memerintah, memohon, menuntut, menentang dan memberi nasehat.

c) Komisif: pada tuturan ini penutur sedikit banyak terikat pada suatu tindakan di masa 
depan misalnya menjanjikan, menawarkan. Jenis ilokusi ini cenderung berfungsi menyenangkan dan kurang bersifat kompetitif karena tidak mengacu pada kepentingan penutur tetapi pada kepentingan petutur (mitra tutur).

d) Ekspresif: tuturan ini biasanya digunakan untuk mengungkapkan atau mengutarakan sikap psikologis penutur terhadap keadaan yang tersirat. Contohnya adalah mengucapkan terima kasih, mengucapakan selamat, memberi maaf, mengecam, memuji, mengucapkan belasungkawa dan sebagainya. Tindak tutur ekspresif cenderung menyenangkan karena secara intrinsik mengacu pada prinsip kesopanan, kecuali untuk mengecam atau menuduh.

e) Deklarasi: berhasilnya pelaksanaan tuturan ini akan mengakibatkan adanya kesesuaian antara isi proposisi dengan realitas. Contohnya adalah mengundurkan diri, memberi nama, memecat, membaptis, menjatuhkan hukuman, mengucilkan/membuang dan sebagainya. Tindak-tindak tersebut merupakan tindak ujar yang sangat khusus karena tindak itu biasanya dilakukan oleh seorang yang diberi wewenang untuk melakukanya.

Masing-masing fungsi ini dapat teridentifikasi bahaso jaek jika ada konteks yang mewadahiya (Revita, 2013).

Konteks dapat mengacu pada tuturan sebelum dan sesudah tuturan yang dimaksud petutur, mengacu kepada keadaan sekitar yang berkaitan dengan kebiasaan, partisipasi, adat istiadat, dan budaya masyarakat. Konteks juga dapat mengacu pada kondisi fisik, mental, serta pengetahuan yang ada di benak penutur maupun petutur. Unsur waktu dan tempat terkait erat dengan hal-hal tersebut.

Istilah konteks pertama kali diperkenalkan oleh Malinowski (1923:307) dengan sebutan konteks situasi. Ia merumuskan konteks situasi seperti di bawah ini:

"Exactly as in the reality of spoken or written languages, a word without linguistic context is a mere figment and stands for nothing by itself, so in the reality 
of spoken living tongue, the utterance has no meaning except in the context situation".

Sejalan dengan pendapat

Malinowski, Firth (dalam Brown dan Yule,1996) juga menyinggung konteks situasi untuk memahami suatu ujaran. Menurut Firth, konteks situasi menghubungkan tiga kategori, yaitu: (a) ciri-ciri yang relevan dari peserta; orang-orang, kepribadian, (b) tujuantujuan yang relevan, (c) akibat perbuatan verbal.

Leech (1983) dan Ochs (dalam Levinson, 1983:23) memberikan konteks sebagai salah satu komponen dalam situasi tutur. Menurut Leech, konteks didefinisikan sebagai aspekaspek yang berkaitan dengan lingkungan fisik dan sosial sebuah tuturan. Leech menambahkan dalam definisinya tentang konteks yaitu sebagai suatu pengetahuan latar belakang yang secara bersama dimiliki oleh penutur dan petutur dan konteks ini membantu petutur menafsirkan atau menginterpretasikan maksud tuturan penutur.

\section{HASIL DAN PEMBAHASAN}

Dalam penggunaannya, bahaso jaek masyarakat Siulak Kabupaten Kerinci memiliki tiga fungsi representatif, direktif, dan, ekspresif

\section{a. Fungsi Direktif}

Data Pantek mpun! Lah toh ngahu

1 akau lho

'Pantatmu lah! Jangan ganggu aku terus'

Tuturan (1) merupakan bahaso jaek. Tuturan ini disampaikan seorang laki-laki kepada temannya supaya tidak menganggu dia lagi. Meskipun sudah berkali-kali diberitahu supaya tidak menganggu, temannya tetap mengganggu. Permintaan untuk tidak diganggu disampaikan penutur lewat bahaso jaek seperti data (1) di atas.

Pantek mpun adalah salah satu bahaso jaekyang sangat kasar sebagai ungkapan kemarahan atau ketidaksukaan terhadap lawan tutur. Kata Pantekdalam data 1 dimaksudkan untuk fungsi direktif yakni permintaan. Permintaan ini merupakan tindakan agar mitra tutur tidak berbuat sesuatu yang menganggu orang lain sehingga menimbulkan kemarahan.

Data 2 Jangan bayuk! Awak
nyado lum nikah
'Jangan bersetubuh!
Kalian belum nikah.'

Tuturan ini adalah bahaso jaek yang merujuk kepada hubungan seksual. Tuturan ini dituturkan oleh orang tua kedapatan sepasang laki-laki 
dan perempuan berdua-duaan di sekitar kebunnya. Sepasang laki-laki dan perempuan itu terkejut dan malu ketahuan sama pemilik kebun.

Kata bayuk dalam data 2 dimaksudkan untuk fungsi direktif melarang dan sekaligus menasehati lawan tutur akan sesuatu hal yang dikerjakan. Penggalan tuturan menggunakan kalimat langsung “ Awak nyado lum nikah" yang ditujukan kepada sepasang laki-laki dan perempuan mempunyai fungsi untuk menasehati.

Kata bayuk sering juga diasosiasikan dengan tindakan-tindakan yang dapat berujung pada perzinaan, seperti berdua-duaan di tempat sepi, atau bermesraan di tempat umum. Kata bayuk merupakan kegiatan atau tindakan berhubungan badan atau bersetubuh.

Kegiatan yang berhubungan dengan seksual, seperti hubungan seksual juga merupakan topik yang dianggap tabu oleh masyarakat Siulak. Hubungan seksual merupakan hal yang bersifat personal dan tidak seharusnya diumbar pada tempat umum. Selain itu, dalam masyarakat Siulak terdapat aturan atau norma adat dan norma agama yang membatasi penggunaan kata-kata yang berhubungan dengan hubungan seksual pada usia tertentu dimana seseorang dianggap sudah dewasa dan layak mengetahui hal-hal yang berhubungan dengan hubungan seksual.

Penggunaan kata yang berhubungan dengan hubungan seksual dianggap tabu atau dianggap bahasojaek jika dituturkan oleh seseorang yang dianggap belum cukup umur. Bayuk adalah bahaso jaek yang tidak boleh dituturkan disembarangan tempat.

\section{b. Fungsi Ekspresif}

Data Pyo dak do nyan ngan tau 3 mpun, lauk baek ngan panjang 'Kenapa tidak ada satupun yang kamu tau, penismu saja yang besar'

Kata lauk merupakan salah bentuk dari bahaso jaek. Dalam data 3, kata lauk dimaksudkan untuk fungsi ekspresif, yaitu mengekspresikan kekesalan dan kemarahan. Kemarahan ini muncul karena penutur menilai mitra tutur tidak mampu mengerjakan setiap hal yang dia perintahkan. Setiap pekerjaan yang diminta untuk dilakukan, mitra tutur selalu gagal.

\section{Data Pio mpun babin nyan?}


'Kenapa kamu bandel betul?

Tuturan (4) disampaikan oleh seorang ibu kepada anak laki-lakinya yang tidak mau mendengar apa yang diperintahkannya. Merasa sudah mengingatkan berkali-kali, tetapi tetap mendengar, penutur menjadi marah. Akibatnya, kemarahan disampaikan melalui bahaso jaek.

Data 4 dimaksudkan untuk fungsi ekspresif. Penggunaan kata babin dalam kalimat merupakan ungkapan kemarahan. Hal ini dikarenakan penggunaan kata babin hanya diujarkan oleh orang yang berpengaruh kepada mitra tutur, seperti ibu kepada anaknya dan yang usia lebih besar kepada usia yang kecil.

\section{c. Fungsi Representatif}

Bahaso jaek juga memiliki fungsi representatif dalam penggunaannya karena dimaksudkan untuk menyatakan atau memberi informasi. Contohnya dapat dilihat pada data (3), (19), dan (20).

\section{Data Ado kau ngimak auk itu, cipek 5 nyo nyan liba \\ 'Ada kamu lihat perempuan itu, vaginanya saja yang lebar'}

Pada tuturan (5) di atas, penggunaan bahaso jaekcipek nyo nyan liba merupakan bentuk penghinaan terhadap lawan tutur. Secara literal, cipek nyo nyan libamengacu kepada 'kemaluan perempuan itu lebar'. Ketika kemaluannya dikomentari, seorang perempuan akan merasa sangat tersinggung.

Atas dasar untuk mempermalukan mitra tutur, penutur memilih menggunakan bahaso jaek seperti (5) di atas. Tuturan di atas dapat menjatuhkan harga diri dan martabat lawan tutur, terlebih lagi jika di ujarkan di depan publik.

Dalam koteks di atas, penutur memberi tahu bahwa vaginanya lebardengan mengatakan cipek nyo nyan liba. Tuturan ini dikategorikan berfungsi representatif karena bersifat memberitahu.

Kata cipek sering juga digunakan untuk merujuk kepada orang kedua dengan menggunakan kalimat yang lebih sederhana, seperti

\section{Data Pumen mpun nyan suman 6 ngan bruk 'Wajahmu seperti monyet.'}

Tuturan (6) di atas dituturkan oleh seorang penutur kepada temannya yang sombong. Temannya ini merasa sangat percaya diri dengan keberadaan adalah fisiknya. Merasa tidak nyaman dengan 
perilaku temannya ini, penutur mengatakan Pumen mpun nyan suman ngan bruk.

Tuturan ini berfungsi untuk memberitahu bahwa wajah mitra tutur seperti monyet. Meskipun ada maksud lain yaitu untuk menghina, tetapi dengan mengatakan Pumen mpun nyan suman ngan bruk, mitra tutur sadar dengan kondisi dia yang sesungguhnya.

\section{Data Kalakun mpun nyan suman 7 ngan anjek 'Kelakuanmu seperti anjing.'}

Tuturan (7) di atas dituturkan oleh seorang laki-laki kepada seseorang yang berusia lebih muda. Penutur melihat perilaku lawan tutur tidak sesuai dengan dengan norma masyarakat Siulak Kerinci. Meskipun sudah diberitahu berkali-kali, lawan tutur tidak menggubris. Untuk itu, dia mengatakan Kalakun mpun nyan suman ngan anjek.

Pada tuturan (7) di atas, penutur menyamakan lawan tutur dengan 'anjing'. Bentuk perumpamaan tersebut merujuk pada sikap dan perilaku lawan tutur yang menyerupai anjing.

Penggunaan kata anjek merupakan bentuk penghinaan yang sangat kasar dalam masyarakat Siulak. Anjek yang bermakna anjing merupakan binatang yang sangat hina dan rendah dalam konteks sosial masyarakat Siulak. Oleh karena itu, penggunaan bentuk penyerupaan seperti frasa suman ngan anjek merupakan bentuk tindakan mengancam muka lawan tutur.

\section{SIMPULAN}

Bahaso jaek yang digunakan masyarakat Siulak Kabupaten Kerinci memiliki tiga fungsi, yaitu (1) direktif, (2) ekspresif, dan (3) representatif. Fungsi yang paling sering digunakan adalah ekspresif.

Fungsi ekspresif dalam bahaso jaek memiliki potensi yang tinggi untuk membuat malu, menghilangkan harga diri, dan merendahkan orang lain. Melalui penggunaan bahaso jaek, masyarakat bisa lebih ekspresif mengungkapkan perasaan. Selain itu, bahaso jaek juga dipakai sebagai alat pengungkapan ketidaksukaan atau kebenciaan kepada lawan tutur.

\section{DAFTAR PUSTAKA}

Allan, Keith dan Kate Burridge. 2006. Forbidden Words: Taboo and the Censoring of Language. Cambrodge University Press: Cambridge.

Brown, Penolope dan Stephen C Levinson. 1987. "Universals in Language Usage: Politeness Phenomena". Dalam Question and Politeness. Penyunting Esther 
N Goody. Cambridge: Cambridge University Press.

Chaer, Abdul. 1994. Linguistik Umum. Jakarta : PT Rineka Cipta

Jay, Timothy. 1999. Why We Curse: A Neuro-psycho-social Theory of Speech. John Benjamins: Philadelphia

Kusmana, A., \& Afria, R. (2018). ANALISIS UNGKAPAN MAKIAN DALAM BAHASA KERINCI: $\quad$ STUDI SOSIOLINGUISTIK. Titian: Jurnal Ilmu Humaniora, 2(02), 173 -. Retrieved from https://onlinejournal.unja.ac.id/titian/article/vie $\underline{\mathrm{w} / 6090}$

Leech, Geoffrey. 1983. Prinsip-prinsip Pragmatik. Diterjemahkan oleh Dr.M.D.D OKA, MA. Jakarta: Universitas Indonesia

Oktavianus, dan Ike Revita. 2013. Kesantunan dalam Bahasa Minangkabau. Padang: Minangkabau Press

Revita, Ike. 2013. Pragmatik : Kajian Tindak Tutur Permintaan Lintas Bahasa. Padang : Universitas Andalas

Searle, J.R. 1969. Speech Act. Cambridge: Cambridge University Press.

Sudaryanto. 1993. Metode dan Aneka Teknik Analisis Bahasa. Yogyakarta: Duta Wacana University Press.

Usman, Amir Hakim. 1988. Fonologi dan Morfologi Bahasa Kerinci Dialek Sungai Penuh. Disertasi Doktor, tidak diterbitkan, Universitas Indonesia, Jakarta.

Wardhaugh,Ronald. $2010 . \quad A n$ Introduction to Sociolinguistics. Wiley Blackwell: United Kingdom
Yule, George.1996. Pragmatics. Oxford: Oxford University Press. 